\title{
The Recognition at Common Law of Nigerian Adoption Orders in the UK and the Role of the 1993 Hague Convention on Inter-country Adoption in Nigeria: Learning from Re V (A Child) (Recognition of Foreign Adoption) [2017] EWHC 1733 (Fam)
}

\author{
Onyója Momoh \\ Family Law Barrister at 5 Pump Court Chambers, Temple London EC4Y 7AP \\ Postdoctoral Research Fellow at the Centre for Private International Law, University of Aberdeen, Scotland
}

AB24 3FX

\begin{abstract}
As a non-contracting party to the 1993 Hague Convention on Protection of Children and Co-operation in Respect of Inter-country Adoption, Nigerian inter-country adoptions are not 'Convention' adoptions nor are they afforded 'recognition' in a straightforward way. In the UK, an application to the High Court under the inherent jurisdiction for the recognition of a foreign order is the only route available to the applicants and remains the only route available for Nigerian adoption orders. This article argues that the benefits for Nigeria of acceding to the 1993 Hague Convention are far reaching, the default position of recognition at common law is not sustainable. The best interests and welfare of the Nigerian child demands a robust and protective practice of inter-country adoption and the recognition of foreign adoptions.
\end{abstract}

Keywords: Intercountry adoption, recognition of foreign adoption, children rights, protection of children, Nigeria, Treaties, 1993 Hague Convention

DOI: $10.7176 / \mathrm{JLPG} / 98-18$

Publication date:June 30th 2020

\section{Introduction}

Nigeria is not a signatory to the 1993 Hague Convention on Protection of Children and Co-operation in Respect of Intercountry Adoption ("1993 Hague Convention") to enable Convention adoptions, and where it concerns the UK, it is no longer on the list of designated countries through which a foreign adoption may still be recognised by English law. ${ }^{1}$ In the case of Re V (A Child) (Recognition of Foreign Adoption) [2017] EWHC 1733 (Fam), Mrs. Justice Pauffley allowed the application for recognition of a Nigerian adoption order in respect of ' $V$ ', a two-yearold adoptive son of $\mathrm{Mr}$ and Mrs W. An application to the High Court under the inherent jurisdiction for the recognition of a foreign order was the only route available to the applicants and remains the only route available for Nigerian adoption orders.

\section{The Facts}

The case concerned a little boy "V", aged 2 years, who was a Nigerian national. The parties, Mr and Mrs W were a married couple on a UK Tier 2 visa, and therefore lawfully resident in the UK. They sought to bring their adoptive son to live with them in the UK. Their intention was to return to Nigeria once Mr W had completed and attained a qualification for his medical placement. ${ }^{2}$ The child lived in Nigeria with maternal relatives but Mr and Mrs W had contact with V using social media almost every day. ${ }^{3}$ During the proceedings, it was observed by the judge that the 'strain' of being separated from her son was 'all too evident' when Mrs W gave oral testimony. The UK immigration authorities refused V entry into the UK under the immigration rule HC 395 Paragraph $319 \mathrm{H}$ to live with his adoptive parents on the basis that $\mathrm{Mr}$ and Mrs $\mathrm{W}$ were not recognised as V's parents. ${ }^{4}$

$\mathrm{Mr}$ and Mrs W were not able to apply under section 57 of the Family Law Act 1986 for a declaration that V is their adopted child - this was because V could not satisfy the criteria that he was domiciled in England and Wales at the time of the application or habitually resident there for one year prior to the application. ${ }^{5}$ Neither was it open to $\mathrm{Mr}$ and Mrs W to apply for a domestic adoption order under s.83 of the Adoption and Children Act 2002 and regulation 4(2) of the Adoptions with a Foreign Element Regulations 2005 - this was on the basis that they could not be issued a certificate of eligibility for a foreign adoptive child as they were only temporarily resident in the UK (in other words, they did not have indefinite leave to remain).

Therefore, the only option available to $\mathrm{Mr}$ and $\mathrm{Mrs} \mathrm{W}$ was to pursue the recognition of the Nigerian adoption

\footnotetext{
${ }^{1}$ See Adoption (Recognition of Overseas Adoptions) Order 2013/1801, in effect since 3 January 2014.

${ }^{2} \operatorname{Re} V$ (A Child) (Recognition of Foreign Adoption) [2017] EWHC 1733 (Fam) para 1 (hereafter 'Re V (A Child)/ Re V'). Cf. ELO v CLO (recognition of a Nigerian adoption order) [2017] EWHC 3574 (Fam).

${ }^{3} \operatorname{Re} V$ (A Child), para 3.

${ }^{4} \operatorname{Re} V(A$ Child $)$, para 2.

${ }^{5}$ Family Law Act 1986, s 57(3).
} 
order under the inherent common law jurisdiction process. The effect of making a recognition order at common law is that Mr and Mrs W will be recognised and treated as the "parents" of their two-year child, especially in the content of immigration law. The parents duly issued and in the course of the proceedings, the Secretary of State for the Home Department ("SSHD") intervened, and an expert on aspects of Nigerian Law was instructed. Although the SSHD appeared to be neutral in their position, from the outset, the SSHD sought a rigorous examination of the issues by the court, in particular in relation to the challenge on domicile ${ }^{1}$, the lawfulness of the adoption ${ }^{2}$ and public policy reasons. ${ }^{3}$

\section{The Decision}

The court acceded to the application for recognition of the Nigeria adoption order of V at common law. Pauffley $\mathrm{J}$ made a finding that the Nigerian adoption order complied with the requirements of foreign law, as per the established principles in Re Valentines Settlement [1965] Ch 831, and further determined that, even in the event that Her Ladyship's assessment was wrong, recognition would still be granted to uphold Article 8 family rights of $\mathrm{Mr}$ and Mrs $\mathrm{W}$ and $\mathrm{V} .{ }^{4}$

In reaching her decision, Pauffley $\mathrm{J}$ set out in her judgment the legal framework and four criteria for recognition ${ }^{5}$ under the Court of Appeal case of Re Valentines Settlement [1965] Ch 831:6

(i) The adoptive parents must have been domiciled in the foreign country at the time of the foreign adoption;

On the issue of domicile, it was asserted by the SSHD that Mr and Mrs W had not retained their Nigerian domicile of origin ${ }^{7}$ and therefore, they could not satisfy the first criterion. The leading House of Lords decision in Mark v Mark [2006] 1 AC 98 sets out the guiding principles ${ }^{8}$ by Baroness Hale on the issue of domicile. A key question arose as to whether the Nigerian authorities had treated $\mathrm{Mr}$ and $\mathrm{Mrs} \mathrm{W}$ as being domiciled in England and Wales during the time of the adoption. The SSHD drew attention to a letter from a professional at the Ministry of Women's Affairs and Social Development, Nigeria, that purported to indicate that the applicants and V were domiciled in the United Kingdom. The judge, having considered the arguments, was persuaded that the writer of that letter was conveying that the applicants lived in the UK as opposed to having their domiciled there. The judge referred to an expert report prepared for the purposes of the proceedings by a Nigerian law expert, Mr Badejo, which indicated that the question of legal domicile was not a relevant consideration within adoption proceedings in Nigeria. ${ }^{9}$ The judge then went on to considered other factors relevant to domicile, and concluded that the applicants had both preserved their status as civil servants in Nigeria, retained their home, continued to invest in Nigerian share portfolio, had rented a Nigerian residential investment property, had a close family, social, cultural and employment attachments to Nigeria and the maternal family have been actively involved in V's care, ${ }^{10}$ The judge was satisfied that the applicants' legal home was in Nigeria and that, therefore, they had not abandoned their domicile of origin.

(ii) The child must have been legally adopted in accordance with the requirements of the foreign law;

The SSHD sought to challenge the legality of the adoption process on the basis of two inconsistencies: first, that the applicants had, whether knowingly or not, misled the Nigerian court as to the extent of time spent with $\mathrm{V}$ before adoption, and second, their presence and residence in Nigeria before the adoption hearing. In this regard, the court was tasked with inquiring into and making an assessment of the law and facts in relation to this requirement and on the face of the inaccuracies. The judge was again assisted by Mr Badejo's expert report ${ }^{11}$ who concluded that the adoption order was valid and in accordance with the requirements of Nigerian law. The judge was also persuaded by the quality of Mrs W's oral evidence which she described as 'honest and reliable'12 when she heard the explanations for the discrepancies. The judge found that there was no intention to mislead. Under

\footnotetext{
${ }^{1}$ Re V (A Child) para 19

2 ibid, para 29

3 ibid, para 50

${ }^{4}$ ibid, para 14

5 ibid, para 60

${ }^{6}$ Principles that were upheld by Sir James Munby in the case of $N$ (A Child) [2016] EWHC 3085.

7 ibid, para 16 .

${ }^{8}$ Mark v Mark [2006] 1 AC 98 - para 37 provides: "A person must always have a domicile but can only have one domicile at a time. Hence it must be given the same meaning in whatever context it arises". Para 44 states: "The object of the rules determining domicile is to discover the system of law with which the propositus is most closely connected for the range of purposes mentioned earlier. ... the concept of domicile is not that of a benefit to the propositus. Rather it is a neutral rule of law for determining that system of personal law with which the individual has the appropriate connection, so that it shall govern his personal status and questions relating to him and his affairs."

${ }^{9} \mathrm{Re}$ V (A Child) para 21: report by Mr Abimbola Badejo, on Aspects of Nigerian Law.

${ }^{10}$ ibid, para 27

11 ibid, para 32

12 ibid, para $35-38$
} 
Nigerian law, ${ }^{1}$ there is a requirement that the child should be in the care of one or both of the applicants for a period of 3 consecutive months before the order, but this had not been satisfied. Mrs $\mathrm{W}$ had cared for $\mathrm{V}$ for a period of $2^{1 / 2}$ months and these were not consecutive. Nevertheless, the expert did not conclude that this was sufficient to find that the adoption was neither legal nor valid. The judge found that $\mathrm{V}$ was adopted in accordance with the foreign law requirements, satisfying the condition.

(iii) The foreign adoption must in substance have the same essential characteristics as an English adoption.

Fundamentally, this requirement raises the following question: 'Did the concept of adoption in the foreign jurisdiction substantially conform with the English concept of adoption? The essential characteristic of English adoption is the severance of the legal relationship between a child and their natural parents and the creation of one between the child and their adoptive parents. The judge was persuaded that, with reference to section 138 of the State's Child Rights $\mathrm{Law}^{2}$ and the analysis in the expert report, the Nigerian adoption has in substance the same essential characteristics as an English adoption.

(iv) There must be no reason in public policy for refusing recognition.

The SSHD sought to argue that, on the basis that the Nigerian court may have been misled given the discrepancies referred to, the public policy consideration had been evoked. In this regard, the judge relied on her findings that $\mathrm{Mr}$ and Mrs $\mathrm{W}$ had not sought to mislead the court and therefore there were no public policy reasons why recognition should be refused.

\section{Comment}

Why should Nigeria accede to the 1993 Hague Convention on Protection of Children and Co-operation in Respect of Intercountry Adoption?

It is very well established that the English court has an inherent jurisdiction at common law to recognise foreign adoptions even though the country concerned is not a Contracting Party to the 1993 Hague Adoption Convention. Recognition under common law is a last resort, because even a non-Convention adoption can be recognised in England and Wales if the country concerned is on the 'designated list' in accordance with the Adoption (Recognition of Overseas Adoptions) Order 2013. The approach of $\operatorname{Re} V$ to an application for recognition of a foreign adoption pursuant to the court's inherent common law jurisdiction was clearly established as far back as 1965 in Re Valentine's Settlement and that authority has been consistently applied. Recognition at common law will always require applicants to satisfy the Re Valentine's Settlement criteria of (1) domicile (2) legally adopted (3) essential characteristics (4) no reason in public policy for refusing recognition. Nevertheless, it is of note that in $Q S v R S \&$ Anor [2016] EWHC 2470 (Fam) MacDonald J warned against the strict application of Re Valentine's Settlement where it would constitute a clear interference with the parents and child's Article 8 rights to family life. $^{3}$

As it stands, the only remedy available in the UK to children adopted under Nigerian law is recognition according to common law principles established by Re Valentines Settlement. There is a lack of adequate crossborder co-operation in intercountry adoption and the recognition of a foreign adoption. In focusing on the latter issue of recognition and in keeping with the essence of the case of $R e V$, that too can be effectively addressed through the framework of the 1993 Hague Convention.

Nigeria can address this by ratifying and implementing the 1993 Hague Convention on Intercountry Adoption. To echo the words of Sir Mathew Thorpe, the Hague Conference is indeed challenged by the paucity of African jurisdictions implementing them, including Nigeria, but we must focus on jurisdictions such as Nigeria and Ghana in the West. ${ }^{4}$ Not only would operating the convention result in Convention-compliant intercountry adoptions, but in England and Wales, it would mean that Nigerian adoptions will re-join ${ }^{5}$ the designated list of overseas adoptions that are automatically recognised by English law. Accession to the 1993 Hague Convention would reinforce the UN Convention on the Rights of the Child (art 3 and 21) and it would help prevent abduction, the sale of or trafficking of children. The 1993 Convention seeks to promote and uphold the best interests of the child in the context of inter-country adoption through, inter alia, co-operation between the state of origin and the receiving state throughout the entire adoption procedure.

Article 4 sets out the principle that the competent authority of the state of origin is required to establish that, in accordance with the law of the state of origin, the child is adoptable; ${ }^{6}$ that adoption is in the child's best

\footnotetext{
${ }^{1}$ Child Rights Act 2003, s 128.

${ }^{2}$ Re V (A Child) para 48

${ }^{3}$ See precedent set in Wagner $v$ Luxembourg [2007] ECHR 76240/01

${ }^{4}$ Thorpe M, 'The Commonwealth and the Hague Family Conventions' (2015) IFLJ, issue 3, pp. 249-254, 251

${ }^{5}$ Prior to 3 January 2014, Nigeria was on the designated list in the Adoption Order 2013, as a consequence of having not ratified the 1993 Hague Convention, Nigeria is no longer on the list.

${ }^{6}$ Article 4(a)
} 
interests; ${ }^{1}$ that the birth parents have been counselled about the effects of their consent for the child be to adopted; ${ }^{2}$ that such consent was given freely ${ }^{3}$ and was not occasioned by payment or compensation; ${ }^{4}$ that the mother had given consent, ${ }^{5}$ where required, after the birth of the child; taking into account the age and degree of maturity of the child, that child too has been counselled ${ }^{6}$ has given consent not occasioned by payment or compensation ${ }^{7}$ and has had his or her wishes and opinions taken into account. ${ }^{8}$

Article 5 addresses the eligibility and suitability of the prospective adopter(s), in that they have been determined by the competent authority of the receiving state in accordance with the law of that state to be eligible and suited to adopt; $;{ }^{9}$ have had access to counselling where necessary, ${ }^{10}$ and have determined that the child is or will be able to enter and reside permanently in the receiving state. ${ }^{11}$

The functions of the designated Central Authority ${ }^{12}$ may be performed by public authorities or by bodies accredited under Chapter III of the Convention. ${ }^{13}$ The Convention takes into account Federal States in countries with more than one system of law such as Nigeria and makes provision for the appointment of more than one Central Authority with a specified territory and functions. ${ }^{14}$ The Convention contains provisions concerning other essential aspects of intercountry adoption proceedings, from staying alert to improper financial gain ${ }^{15}$ to preparing a comprehensive report on the child. ${ }^{16}$ In addition, Article 23 provides that an adoption which has been certified as being in accordance with the 1993 Hague Convention by the competent authority of the State of the adoption shall be recognised by operation of law in the other Contracting States. ${ }^{17}$ The effect of recognition under the 1993 Hague Convention includes the acceptance of the "legal parent-child relationship" between the adoptive parents and their child, ${ }^{18}$ parental responsibility of the adoptive parents for the chid ${ }^{19}$ and the termination of any "preexisting legal relationship between the child and his or her mother and father". ${ }^{20}$

In $2016,{ }^{21}$ the $\mathrm{HCCH}$ conducted preliminary research on the issue of cross-border recognition of domestic adoption and the complex issues that arise from a refusal to recognise the domestic adoption cross-border. ${ }^{22}$ In engaging member States to participate in this investigative work, the collated responses gave insight into the reasons and indeed, the benefits of why families would seek cross-border recognition. These included to "establish the adopted child's legal parentage in the recognising State; ${ }^{23}$ ensure that the adoption is valid in the State to which the family intends to relocate ${ }^{24}$ obtain a birth certificate in the recognising State for the adopted child: ${ }^{25}$ obtain (or retain) the nationality of the recognising State for the adopted child ${ }^{26}$ obtain a visa to enter the recognising State for the adopted child; ${ }^{27}$ obtain rights of residence in the recognising State for the adopted child; ${ }^{28}$ obtain identity documents in the recognising State for the adopted child; ${ }^{29}$ and record the adoption in the registry of the

\footnotetext{
${ }^{1}$ Article 4(b)

${ }^{2}$ Article 4(c)(1)

${ }^{3}$ Article 4(c)(2)

${ }^{4}$ Article 4(c)(3)

${ }^{5}$ Article 4(c)(4)

${ }^{6}$ Article 4(d)(1)

7 Article 4(d)(4)

${ }^{8}$ Article 4(d)(3)

${ }^{9}$ Article 5(a)

${ }^{10}$ Article 5(b)

${ }^{11}$ Article 5(c)

${ }^{12}$ Article 6. With the exception of the functions set out in Article 7.

${ }^{13}$ Article 22.

${ }^{14}$ Article 6(2)

${ }^{15}$ Article 8

${ }^{16}$ Article 14.

${ }^{17}$ Article 23.

${ }^{18} 1993$ Hague Convention, Article 26 (a)

191993 Hague Convention, Article 26 (b)

${ }^{20} 1993$ Hague Convention, Article 26 (c)

${ }^{21}$ HCCH Permanent Bureau, 'Report on the Cross-Border Recognition of Domestic Adoptions', Council on General

Affairs and Policy of the Conference (March 2019) Preliminary Doc No 12 of December 2019. See also Parra-Aranguren G, for the HCCH Permanent Bureau, 'HCCH Questionnaire on the Recognition of Domestic Adoptions in Other States', (2016) Explanatory Report on the Convention of 29 May 1993 on Protection of Children and Co-operation in Respect of Intercountry Adoption.

${ }^{22}$ A refusal to recognise a domestic adoption cross-border could lead to the problem known as 'limping legal parentage' where the child would have different legal parents according to different States and would result, amongst others to the problems of acquiring nationality for that child as well as issues of maintenance and inheritance.

${ }^{23} \mathrm{HCCH}$ Permanent Bureau, Report on the cross-border recognition of domestic adoptions, Council on General Affairs and Policy of the Conference (March 2019) Preliminary Doc No 12 of December 2019, pages 7-8, para III (2) 15

${ }^{24}$ Page 7 , para III (2) 15

${ }^{25}$ Page 8, para III (2) 15

26 ibid

27 ibid

${ }^{28}$ ibid

29 ibid
} 
recognising State (where the registry has not permitted the recording in the first instance, recognition may be sought)". ${ }^{1}$

There is no obvious data, accessible information or precise statistics on the issue of intercountry adoption or recognition of foreign adoption between the UK and Nigeria. Nevertheless, in the U.S. (a 1993 Hague Convention country) for example, official government statistics shows that the number of intercountry adoptions between the US and Nigeria from 1999 to 2018 was 2096. In 2019, 116 intercountry adoptions took place, with Nigeria, the highest ranking African country and $8^{\text {th }}$ of the 80 countries worldwide ${ }^{2}$ Thus, although it may be difficult to come to a firm conclusion about the volume or impact where the UK is concerned, it is significant that in $R e V$, Pauffley $\mathrm{J}$ observed that the "strain upon them [adoptive parents]... of being separated from their long waited and muchloved son was all to evident when Mrs W gave evidence." 3 There is no doubt that many parents faced with this predicament can identify with the burden and even beyond. Note how the 1993 Hague Convention recognises that adoptive parents too may require counselling as a result of the process of adoption. The impact, therefore, of the added layer of uncertainty, protracted by initial refusal under immigration law, the costs and international dimension are very real and present experiences for parents of overseas adoptions. The magnitude of the problem may also be compounded by difficulties related to satisfying the Re Valentines Settlement principles. It is noteworthy that, in this case, the parents had to go through an unsuccessful immigration process first to realise that their foreign adoption order was not automatically recognised, and this is not an isolated experience. ${ }^{4}$ The benefits for Nigeria of acceding to the 1993 Hague Convention are far reaching. Firstly, it gives effect to Articles 3 and 21 of the UNCRC which provides that the best interests of the child should be the paramount consideration in adoption. Secondly, it creates a co-operation framework from the beginning and establishes minimum standards and safeguards through a uniform Convention language that promotes mutual trust and co-operation. Last but not least, it reduces the enormous emotional distress, expense, delays and uncertainty faced by all those concerned. For the Nigerian child, these issues are inimical to the welfare of that child and can, and must, be prevented.

\section{Conclusion}

The benefits for Nigeria of acceding to the 1993 Hague Convention are far reaching. Firstly, it gives effect to Articles 3 and 21 of the UNCRC which provides that the best interests of the child should be the paramount consideration in adoption. Secondly, it creates a co-operation framework from the beginning and establishes minimum standards and safeguards through a uniform Convention language that promotes mutual trust and cooperation. Last but not least, it reduces the enormous emotional distress, expense, delays and uncertainty faced by all those concerned. For the Nigerian child, these issues are inimical to the welfare of that child and can, and must, be prevented.

\section{References}

Re Valentines Settlement [1965] Ch 831

Mark v Mark [2006] 1 AC 98

Wagner v Luxembourg [2007] ECHR 76240/01

$N$ (A Child) [2016] EWHC 3085

Re V (A Child) (Recognition of Foreign Adoption) [2017] EWHC 1733 (Fam)

ELO $v$ CLO (recognition of a Nigerian adoption order) [2017] EWHC 3574 (Fam)

AMDK v NA [2020] EWHC 1548 (Fam)

Thorpe M, 'The Commonwealth and the Hague Family Conventions' (2015) IFLJ, issue 3, pp. 249-254

Parra-Aranguren G, for the HCCH Permanent Bureau, 'HCCH Questionnaire on the Recognition of Domestic Adoptions in Other States', (2016) Explanatory Report on the Convention of 29 May 1993 on Protection of Children and Co-operation in Respect of Intercountry Adoption.

HCCH Permanent Bureau, 'African Regional Conference on the HCCH Children's Conventions' Conclusions and Recommendations, University of the Western Cape (UWC), Cape Town, South Africa, 2-3 April 2019

Etomi E and Asia E of Chief Rotimi Williams' Chambers (FRA Law), Family law in Nigeria, A Q\&A guide to family law in Nigeria, International Academy of Family Lawyers, 1 May 2019

HCCH Permanent Bureau, 'Report on the Cross-Border Recognition of Domestic Adoptions', Council on General Affairs and Policy of the Conference (March 2019) Preliminary Doc No 12 of December 2019

Bureau of Consular Affairs, U.S. Department of State, Fiscal Year (2008 to 2019) Annual Report on

\footnotetext{
${ }^{1}$ ibid

${ }^{2}$ Bureau of Consular Affairs, U.S. Department of State, FY 2019 Annual Report on Intercountry Adoption March 2020, page 6: out of 80 counties, the top 10, including Nigeria were China 819, Ukraine 298, Columbia 244, India 241, Bulgaria 134, South Korea 166, Haiti 130, Nigeria 116, The Philippines 94, Liberia 51.

${ }^{3} \operatorname{Re} \mathrm{V}$, para 6.

${ }^{4}$ The writer's own example of i.e. representing a mother seeking the recognition of a Uganda adoption order. See AMDK v NA [2020] EWHC 1548 (Fam) (06 March 2020)
} 
Intercountry Adoption https://travel.state.gov/content/travel/en/Intercountry-Adoption/adopt_ref/adoptionpublications.html (as of 16 June 2020) 